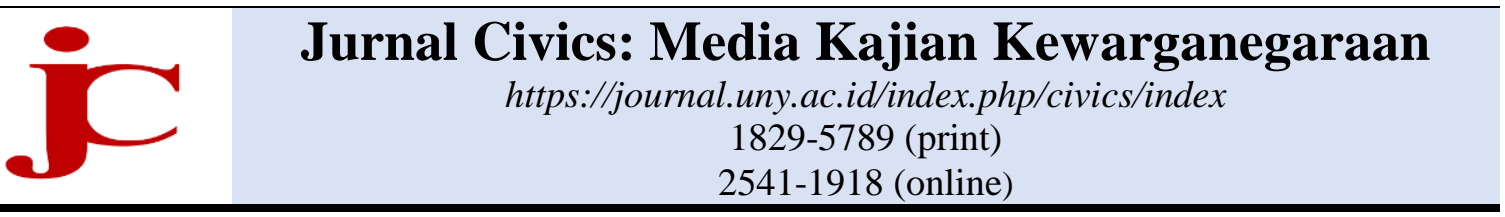

\title{
Implementasi model controversial issue dalam mata kuliah Pendidikan Kewarganegaraan
}

\author{
Alfiandra $^{\text {a, 1*}}{ }^{*}$, Sani Safitri ${ }^{\text {b, }, ~}$, Puspa Dianti c, 3 \\ a, b, c Fakultas Keguruan dan Ilmu Pendidikan, Universitas Sriwijaya, Indralaya, Indonesia \\ ${ }^{1}$ alfiandra62@yahoo.com*; ${ }^{2}$ sani.safitri@yahoo.com; ${ }^{3}$ puspadianti20@yahoo.com \\ *korespondensi penulis
}

\begin{tabular}{ll}
\hline \multicolumn{2}{l}{ Informasi artikel } \\
\hline Sejarah artikel: & \\
Diterima & $: 09-12-2017$ \\
Revisi & $: 02-03-2018$ \\
Dipublikasikan & $: 31-05-2018$ \\
\hline
\end{tabular}

Kata kunci:

Isu kontroversi

Berfikir Kritis

Pendidikan Kewarganegaraan

\begin{abstract}
ABSTRAK
Artikel ini bertujuan untuk menunjukkan efektifitas model pembelajaran controversial issue dalam meningkatkan kemampuan berfikir kritis mahasiswa pada mata kuliah Pendidikan Kewarganegaraan di Unit Pelaksana Teknis Mata Kuliah Pengembangan Kepribadian Universitas Sriwijaya. Metode penelitian yang digunakan adalah penelitian tindakan kelas (classroom action research) sebanyak tiga siklus dimana setiap siklus melalui tahapan perencanaan, pelaksanaan, observasi, evaluasi dan refleksi. Hasil penelitian menunjukkan bahwa implementasi model pembelajaran controversial issue dapat meningkatkan kemampuan berfikir kritis mahasiswa dalam pembelajaran mata kuliah Pendidikan Kewarganegaraan. Peningkatan kemampuan berfikir kritis tersebut terlihat pada keterampilan mahasiswa dalam mengidentifikasi masalah, mendefinisikan masalah, mengeksplorasi masalah, mengevaluasi dan mengintegrasikan berbagai macam solusi menjadi suatu jawaban yang komprehensif terhadap suatu permasalahan.
\end{abstract}

Keywords:

Controversial issue

Critical thinking

Civic Education

\begin{abstract}
The Implementation of controversial issue in Civic Education. This article tries to reveal the effectiveness of controversial issue based teaching model to increase students' critical thinking skills at Unit Pelaksana Teknis Mata Kuliah Pengembangan Kepribadian Universitas Sriwijaya. It was a classroom action research with three cycles, each of which consists of planing, observation, evaluation and reflection. The results reveal that the implementation of controversial issue based teaching model can increase students' critical thinking skills in Citizenship Education Program. This increasing of critical thinking skills was indicated by the skills to identify problem, to define problem, to explore problem, to evaluate, and to integrate any kinds of solutions in order to comprehend the problem.
\end{abstract}

Copyright $\odot 2018$ Alfiandra, dkk)

\section{Pendahuluan}

Pendidikan Kewarganegaraan di perguruan tinggi sebagai program kurikuler merupakan salah satu mata kuliah wajib dalam kelompok mata Kuliah Pengembangan Kepribadian (MPK) yang mengemban misi pengembangan karakter bangsa dalam konteks nation and character building. Pendidikan Kewarganegaraan pada dasarnya merupakan wahana pendidikan karakter yang dikembangkan secara sistematis dan sistemis. 
Pendidikan kewarganegaraan dengan paradigma baru secara konseptual mempunyai tujuan akhir pembelajaran (learning outcomes) adalah terwujudnya kebajikan atau keadaban kewarganegaraan (civic virtues/civility) dalam diri setiap warganegara. Untuk terwujudnya tujuan akhir tersebut menuntut penyelenggaraan Pendidikan Kewarganegaraan yang membekali mahasiswa dengan wawasan pengetahuan kewarganegaraan (civic knowledge), sikap kewarganegaraan (civic disposition), keterampilan kewarganegaraan (civic skill), komitmen kewarganegaraan (civic commitment), kepercayaan diri kewarganegaraan (civic confidence) dan kecakapan kewarganegaraan (civic competence). Dewan Eropa mengajukan konsep-konsep kunci mengenai key competences for lifelong learning yang disorot yakni pentingnya pengetahuan tentang perkembangan, dan institusi yang mencerminkan, demokrasi, keadilan, kesetaraan, kewarganegaraan, dan hak-hak sipil. Ini menarik perhatian pada keterampilan komunikasi, pemecahan masalah, refleksi kritis dan kreatif, pengambilan keputusan, tanggung jawab, menghormati nilai-nilai lain termasuk kesadaran keragaman dan sikap dan nilai-nilai solidaritas, hak asasi manusia, kesetaraan, dan demokrasi (Hoskins, Villalba, Van Nijlen, \& Barber, 2008)

Berkaitan dengan learning outcomes, ketercapainnya salah satunya dapat dievaluasi dari sikap tanggap dan sikap kritis mahasiswa terhadap masalah-masalah yang terjadi dalam kehidupan berbangsa dan bernegara kita. Sikap kritis ini bisa menjadi salah satu indikator pembentuk warganegara yang beradab atau bajik. Sikap kritis itu sendiri muncul dari kemampuan berfikir kritis yang lahir dari pengetahuan, sikap, keterampilan, komitmen, kepercayaan diri dan kecakapan. Dalam lingkup yang lebih luas kemampuan berpikir kritis sangat diperlukan mengingat bahwa saat ini ilmu pengetahuan dan teknologi berkembang sangat pesat dan memungkinkan untuk memperoleh informasi secara cepat dan mudah dari berbagai sumber dan tempat mana pun di dunia yang menuntut setiap orang mempunyai kemampuan mengolah, menilai dan mengambil informasi yang dibutuhkan untuk menghadapi tantangan global. Berpikir kritis adalah sebuah proses sistematis yang memungkinkan individu untuk merumuskan dan mengevaluasi keyakinan dan pendapat mereka sendiri. Berpikir kritis adalah sebuah proses terorganisasi yang memungkinkan seseorang mengevaluasi bukti, asumsi, logika, dan bahasa yang mendasari pernyataan orang lain. Fisher (2009, hal. 7) mengemukakan ciri-ciri berpikir kritis yakni mengenal masalah, menemukan cara-cara yang dapat dipakai untuk menangani masalah-masalah tersebut, mengumpulkan informasi yang diperlukan, mengenal asumsi dan nilai-nilai yang tidak dinyatakan, memahami dan menggunakan bahasa yang tepat dan jelas, menilai fakta dan mengevaluasi pernyataan-penyataan, mengenali adanya hubungan yang logis antara masalah-masalah, menarik kesimpulan dan kesamaan yang diperlukan, menguji kesamaan-kesamaan dan kesimpulan yang disampaikan seseorang, dan menyusun kembali pola-pola keyakinan seseorang berdasarkan pengalaman. Dalam konteks pembelajaran, kemampuan berpikir kritis melibatkan keterampilan kognitif dan disposisi yang dapat dilihat sebagai sikap atau kebiasaan pikiran, termasuk terbuka dan adil, keingintahuan, fleksibilitas, kecenderungan untuk mencari alasan, keinginan untuk mendapat informasi yang baik, dan rasa hormat untuk dan kesediaan menerima dari sudut pandang yang beragam (Lai, 2011). Sementara itu, penilaian dalam berpikir kritis di universitas biasanya terjadi ketika seorang akademisi melihat karya tulis sebagai kesempatan untuk menunjukkan berapa banyak informasi yang telah diperolehnya tentang subjek tertentu dan bukan sebagai kesempatan untuk menunjukkan pemikiran kritis (O’Hare \& McGuinness, 2009).

Untuk menumbuh kembangkan kemampuan berfikir kritis mahasiswa dalam konteks pembelajaran mata kuliah Pendidikan Kewarganegaraan, diperlukan model pembelajaran yang memberi peluang dan kesempatan pada mahasiswa untuk 
mengembangkan sikap kritis mereka dalam menyikapi berbagai masalah-masalah yang muncul dalam kehidupan berbangsa dan bernegara. Dalam konteks berpikir kritis ini, salah satu model pembelajaran yang dapat dipakai adalah model controversial issue. Model ini menyajikan sesuatu isu yang mudah diterima, akan tetapi mudah ditolak oleh orang atau kelompok lain (Komalasari, 2013). Dari model ini harapannya dapat membantu siswa mengembangkan suatu pemahaman dan komitmen terhadap nilai-nilai demokratis, meningkatkan kemauannya untuk ikut dalam kehidupan politik, dan secara positif mempengaruhi isi pemahaman, kemampuan berpikir kritis, dan kecakapan-kecakapan interpersonal.

Hasil penelitian Muhibbin \& Sumardjoko (2016), pembelajaran Pendidikan Kewarganegaraan di perguruan tinggi sangat strategis dalam meningkatkan sikap demokrasi mahasiswa dan implikasinya bagi masyarakat madani. Namun realita di lapangan terkait dengan pelaksanaan pembelajaran PKn belum ideal dalam mengembangkan sikap demokrasi mahasiswa. Kondisi ini ditandai dengan masih rendahnya kemampuan mengidentifikasi suatu permasalahan, mencari kejelasan terhadap suatu permasalahan, memahami konteks permasalahan, mengajukan argumentasi, konsistensi dalam berargumentasi dan menilai argumentasi orang lain. Kalaupun ada mahasiswa yang sudah memiliki kemampuan tersebut hanya sebagian kecil dan dari setiap pertemuan perkuliahan biasanya orang yang sama.

Implikasinya bagi masyarakat madani dan perlu ada dinamika paradigmatis pembelajaran PKn di Perguruan Tinggi dan unsur-unsur yang dapat menopang tegaknya demokrasi yang berimplikasi bagi terciptanya masyarakat madani Hasil refleksi dan evaluasi pembelajaran mata kuliah Pendidikan Kewarganegaraan yang berjalan selama ini, diidentifikasi kemampuan berfikir kritis mahasiswa dalam menanggapi isu-isu kewarganegaraan yang aktual yang terjadi dalam kehidupan berbangsa bernegara belum begitu baik. Idealnya, langkah-langkah model pembelajaran isu-isu kontroversial terdiri atas 6 tahap, yakni orientasi (isu), identifikasi (nilai), eksplorasi (sikap), komparasi (sikapnilai), ekspresi (perasaan), dan refleksi (Suryanto, Elis, 2012). Hasil implementasi model pembelajaran tersebut juga terbukti bahwa pembelajaran Pendidikan berlatar isuisu kontroversial telah beranjak dari tradisi "education about citizenship" menuju "education through citizenship". Education through citizenship adalah konser Pendidikan Kewarganegaraan yang mengutamakan prinsip pelibatan siswa secara aktif dalam belajar dan bekerja, serta pengalaman partisipatif di sekolah maupun di masyarakat. Sedangkan education for citizenship mengutamakan pada proses pembentukan dan pengembangan kompetensi siswa (pengetahuan, pemahaman, sikap, keterampilan, nilai dan disposisi) yang memungkinkan mereka berpartisipasi secara aktif dan memiliki kesadaran atas peran dan tanggung jawabnya di dalam kehidupan (Suryanto \& Nursalim, 2015).

Artikel ini mengimplementasikan model Pembelajaran controversial issue dalam rangka meningkatkan kemampuan berfikir kritis mahasiswa dalam pembelajaran mata kuliah Pendidikan Kewarganegaraan di Unit Pelaksana Teknis Mata Kuliah Pengembangan Kepribadian (UPT MPK) Universitas Sriwijaya.

\section{Metode}

Metode penelitian yang digunakan dalam penelitian ini adalah penelitian tindakan kelas (classroom action research) yaitu penelitian yang dilakukan dalam kelas, melalui proses refleksi, guna meningkatkan kualitas pembelajaran, agar hasil belajar bisa ditingkatkan. Sesuai dengan kaidah penelitian tindakan kelas maka prosedur penelitian berbentuk siklus (cycle) yang mengacu pada model Elliot. Prosedur penelitian direncanakan 3 siklus, dengan asumsi pada siklus pertama, penerapan model belum sempurna (optimal) dan masih terdapat kelemahan. Kelemahan itu akan diperbaiki pada siklus kedua, dengan melakukan treatment atau perlakuan tertentu. Pada siklus 
dua ini juga masih diasumsikan masih terdapat kelemahan yang akan diperbaiki pada siklus tiga. Namun demikian rencana ini bersifat tentative dan fleksibel yang sejalan dengan tujuan penelitian yang dirumuskan.

Prosedur yang dilakukan untuk setiap siklus meliputi perencanaan, pelaksanaan, observasi, evaluasi dan refleksi. Hasil refleksi pertama akan menjadi masukan untuk merancang perbaikan pada siklus kedua. Dari hasil refleksi kedua akan menjadi masukan untuk merancang tindakan perbaikan pada siklus ketiga. Data yang dikumpulkan dalam penelitian ini adalah data yang mengenai kemampuan berfikir kritis mahasiswa dan kemampuan mahasiswa menjawab soal-soal yang memerlukan analisis, sintesis dan evaluasi.

Pengumpulan data dilakukan pada siklus penelitian yang direncanakan. Data untuk siklus pertama diambil pada pelaksanaan perkuliahan ke 1 sampai ke 4. Siklus kedua pada pelaksanaan perkuliahan ke 5 sampai ke 8 dan siklus ke tiga pada pelaksanaan perkuliahan ke 9 sampai 12. Khusus untuk data kemampuan mahasiswa menjawab soalsoal yang memerlukan analisis, sintesis dan evaluasi diambil pada pertemuan ke 4, 8 dan 12.

Teknik pengumpulan data yang digunakan dalam penelitian ini adalah teknik observasi yang digunakan untuk mengumpulkan data tentang kemampuan berpikir kritis mahasiswa dan teknik tes hasil belajar yang akan digunakan untuk mendapatkan data kemampuan mahasiswa menjawab soal-soal yang memerlukan analisis, sintesis dan evaluasi.

\section{Hasil dan Pembahasan}

Pertimbangan mengenai pembelajaran controversial issue berfungsi menggarisbawahi mengenai pentingnya Pendidikan Kewarganegaraan yang baik bahkan sejak usia dini. Jika mahasiswa terbiasa untuk mendiskusikan perbedaan mereka dengan cara yang rasional, mereka akan lebih menerimanya ketika mereka dewasa. Pendidikan kewarganegaraan membantu kaum muda untuk menghadapi situasi konflik dan kontroversial secara luas dan toleran di kehidupan kampus maupun nanti di kehidupan sebenarnya. Pembelajaran isu-isu kontroversial membantu melengkapi mereka untuk memahami konsekuensi dari tindakan mereka dan orang dewasa di sekitar mereka karena di dalam pembelajaran dibiasakan untuk ... how to recognize bias, evaluate an argument, weigh evidence, look for alternative interpretations, viewpoints and sources of evidence; above all to give good reasons for the things they say and do, and to expect good reasons to be given by others (Citizenship Foundation, 2003).

Model controversial issue diperlukan untuk membentuk kemampuan berpartisipasi guna memecahkan masalah-masalah dalam suatu masyarakat demokratis dengan cara berdiskusi. Melalui diskusi dikembangkan instrumen berupa pengembangan nilai, kepastian dan mempertinggi pemahaman terhadap konten kajian dengan harapan dapat membantu peserta didik mengembangkan suatu pemahaman dan komitmen terhadap nilai-nilai demokratis, meningkatkan kemauannya untuk ikut dalam kehidupan politik, dan secara positif mempengaruhi isi pemahaman, kemampuan berpikir kritis, dan kecakapan-kecakapan interpersonal (Hess, 2001; Samsuri, 2011).

Untuk melihat sejauh mana controversial issue ini berperan dalam pembelajaran Pendidikan Kewarganegaraan di perguruan tinggi, dilakukan beberapa siklus pembelajaran. Tahapan yang dilakukan pada setiap siklusnya terdiri atas lima tahap, yaitu perencanaan, pelaksanaan, observasi, evaluasi, dan refleksi. Melalui kelima tahap tersebut diharapkan pada siklus berikutnya terdapat peningkatan terhadap tingkat berpikir kritis mahasiswa. Adapun hasil dari masingmasing di setiap siklus akan diuraikan sebagai berikut:

\section{Siklus Pertama}

Pada tahap perencanan ini peneliti (dosen) menyiapkan bahan ajar berupa artikel yang berisi isu-isu kontroversial yang aktual yang terjadi di kehidupan bermasyarakat dan bernegara yang nantinya akan menjadi bahan untuk didiskusikan. Selanjutnya, peneliti juga 
menyiapkan lembar kisi dan pedoman observasi untuk melihat kemampuan berfikir kritis mahasiswa yang sebenarnya sudah disiapkan pada tahap persiapan. Pada pedoman observasi kemampuan berfikir kritis mahasiswa dikembangkan indikator dan deskriptor berfikir kritis yang mereferensikan pada teori-teori berfikir kritis. Setelah mempersiapkan bahan ajar dan pedoman observasi, peneliti mulai melaksanakan siklus pertama yang berlangsung selama empat kali pertemuan. Adapun materi yang dibahas pada siklus pertama ini adalah mengenai identitas nasional dan demokrasi Kegiatan yang dilakukan pada tahap ini adalah melaksanakan proses pembelajaran menggunakan model pembelajaran controversial issue berdasarkan skenario pembelajaran yang telah disusun seperti yang tercantum dalam RPS. Dosen menyampikan tujuan pembelajaran dan menjelaskan tentang model pembelajaran controversial issue yang akan dipakai dalam proses pembelajaran. Selanjutnya kegiatan inti, pada kegiatan eksplorasi diawali dengan dosen menjelaskan konsep-konsep penting yang berhubungan dengan materi. Dosen memberi stimulus dengan melontarkan isu-isu kontroversial yang terjadi di tengah masyarakat sesuai dengan substansi kajian Pendidikan Kewarganegaraan yang sedang dibicarakan yaitu identitas nasional dan demokrasi. Isu tentang identitas nasional yang dibahas adalah isu "Bendera Indonesia di Buat Terbalik Dalam Buku Panduan Sea Games 2017'. Sedangkan isu tentang demokrasi yang diangkat adalah isu mengenai "Perppu Ormas" dan "Pemilu yang Jujur dan Adil". Mahasiswa diberi kesempatan mencermati artikel yang dibagikan Dosen membagi mahasiswa dalam 8 kelompok. Setiap kelompok bertugas mengidentifikasi masalah apa yang terjadi dalam artikel tersebut, apa penyebabnya dan apa solusi atau pemecahannya lewat diskusi dan brainstorming dalam kelompok mahasiswa mengerjakan tugas tersebut dengan mengumpulkan berbagai informasi dari berbagai sumber yang dapat dijadikan bahan dalam pemecahan isu yang dibahas, diantaranya lewat browsing di internet. Pada kegiatan elaborasi, melalui diskusi kelas setiap kelompok menyajikan hasil diskusi mereka dan ditanggapi dan dikritisi oleh kelompok yang lainnya. Setiap individu diberi kesempatan mengomunikasikan ide, pandangan, gagasan yang disertai argumentasi mereka secara lisan dan mendengarkan pula opini, argumentasi siswa yang lainnya. Pada kegiatan konfirmasi dosen memberikan umpan balik dari jalannya diskusi kelas tentang isu-isu yang dibahas. Memberi penguatan, klarifikasi terhadap konsep-konsep penting dari materi yang dibicarakan. Dosen memfasilitasi mahasiswa untuk melakukan refleksi terhadap berbagai argument, pandangan, dan opini yang muncul pada saat diskusi kelas

Pada kegiatan akhir dosen dan mahasiswa memberikan kesimpulan akhir isu kontroversial yang dibahas. Selama proses belajar mengajar berlangsung dilakukan observasi. Observasi atau pengamatan terhadap jalannya proses perkuliahan pada siklus pertama menunjukkan proses perkuliahan berjalan cukup baik, meskipun ada beberapa hal yang perlu di perbaiki pada siklus berikutnya

Berkaitan dengan kemampuan berfikir kritis mahasiswa yang menjadi fokus penelitian ini, maka dilihat dari deskriptor yang muncul. Kemampuan berfikir kritis mahasiswa dikelompokkan dalam lima kategori yaitu sangat tinggi (jika nilai perolehan $86 \%-100 \%$ ), tinggi (jika nilai perolehan $71 \%-85 \%$ ), sedang (jika nilai perolehan $56 \%-70 \%$ ), kurang (jika nilai perolehan $41 \%$ - 55\%) dan sangat kurang (jika nilai perolehan $0 \%$ ). Hasil observasi tingkat berfikir mahasiswa pada siklus pertama akan digambarkan pada diagram berikut: 



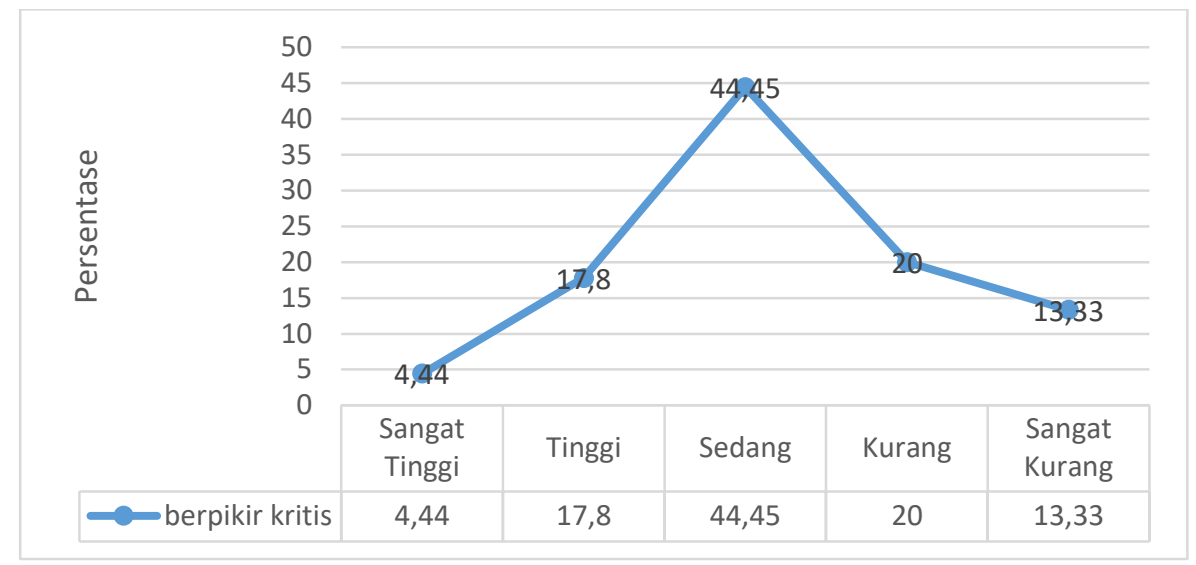

Diagram 1. Kemampuan berfikir kritis mahasiswa pada siklus pertama

Data tersebut menunjukkan bahwa terdapat permasalahan dalam kemampuan berpikir kritis mahasiswa sehingga perlu diberikan tindakan sebagai langkah untuk menindaklanjutinya. Salah satunya adalah dengan melanjutkan penerapan model pembelajaran controversial issue. Model Controversial Issues diperlukan untuk membentuk kemampuan berpartisipasi guna memecahkan masalah-masalah dalam suatu masyarakat demokratis dengan cara diskusi (Lockwood, 1995). Dari model ini harapannya dapat membantu siswa mengembangkan suatu pemahaman dan komitmen terhadap nilai-nilai demokatis, meningkatkan kemauannya untuk ikut dalam kehidupan politik, dan secara positif mempengaruhi isi pemahaman, kemampuan berpikir kritis, dan kecakapan-kecakapan interpersonal. Berdasarkan pendapat yang dikemukakan oleh Lockwood tersebut maka diharapkan melalui implementasi model pembelajaran controversial issue dapat mengatasi permasalahan berfikir kritis mahasiswa. Permasalahan berfikir kritis mahasiswa ini juga didukung dari evaluasi yang didapat pada siklus pertama ini, yaitu kemampuan berfikir kritis mahasiswa masih termasuk kategori frustrasi, di mana hanya 10 orang atau $22.22 \%$ mahasiswa yang memilki nilai kemampuan berfikir kritis tinggi dan sangat tinggi.

Sesuai dengan prosedur penelitian tindakan kelas maka setelah dilakukan observasi dan evaluasi terhadap kemampuan berfikir kritis mahasiswa langkah selanjutnya adalah melakukan refleksi. Refleksi dilakukan untuk mengidentifikasi hal-hal positif dan masalah-masalah yang muncul dalam pelaksanaan pembelajaran dengan menggunakan model pembelajaran controversial issue, untuk diperbaiki pada siklus kedua dengan memberikan perlakuan tertentu (treatment) dengan menjadikan indikator keberhasilan sebagai pedoman. Refleksi dilakukan oleh tim peneliti dan mendengarkan masukkan dari mahasiswa.

Hal-hal positif yang muncul dan ditemukan dalam pelaksanaan siklus pertama ini antara lain (1) mahasiswa terstimulasi untuk mengumpulkan informasi melalui berbagai sumber untuk mengidentifikasi masalah isu identitas nasional dan demokrasi yang didiskusikan disamping mencermati artikel isu yang dibagikan dosen, sebagian mahasiswa juga mencari informasi tambahan lewat browsing di internet. (2) Mahasiswa secara individu lebih bergairah dalam perkuliahan karena terbuka kesempatan untuk berpendapat tentang sesuatu yang ril terjadi di masyarakat. (3) Sebagian besar mahasiswa sudah menunjukkan keterampilan mengidentifikasi masalah dan mendefinisikan/merumuskan masalah dengan baik. Sehingga harapannya pembelajaran kontekstual berbasis controversial issues mendorong siswa memahami hakikat, makna, dan manfaat belajar, sehingga memungkinkan siswa rajin dan termotivasi untuk senantiasa belajar yang terwujud ketika siswa menyadari tentang apa yang mereka perlukan untuk hidup, dan bagaimana cara menggapainya (Mulyasa, 2005). 
Selain hal positif, masalah-masalah yang muncul dalam pelaksanaan siklus pertama ini dan alternative perlakuan (treatment) yang akan dilakukan pada siklus berikutnya. Pertama, observer pada saat melakukan observasi terhadap kemampuan berpikir kritis mahasiswa agak kesulitan mengetahui nama tiap mahasiswa. Alternatif pemecahan adalah pada pertemuan berikutnya semua mahasiswa diminta membuat name tag dari kertas karton agar observer tidak lagi bertanya siapa nama anda kepada mahasiswa ketika mengisi lembar observasi. Dengan adanya name tag ini diharapkan observasi yang dilakukan observer tidak mengganggu konsentrasi mahasiswa

Kedua, ketika diskusi kelompok terlihat beberapa kelompok kurang aktif dan diskusi dalam beberapa kelompok didominasi oleh orang tertentu saja. Alternatif pemecahan yang akan dilakukan pada siklus kedua adalah dosen akan membagi kelompok mahasiswa dengan memperhatikan kemampuan mahasiswa. Pembagian kelompok juga akan dilakukan satu minggu sebelum pertemuan, tidak lagi dibagi dan diberitahukan pada saat perkuliahan dilakukan seperti yang dilakukan pada siklus pertama ini.

Ketiga, batas waktu dalam diskusi kelompok yang diberikan dosen (15 menit) terlewati, karena hampir semua kelompok mengatakan butuh waktu lebih untuk mencoba memahami dan mengidentifikasi masalah atau isu yang dibagikan dosen. Ini mungkin terjadi karena isu yang akan didiskusikan dibagikan pada awal perkuliahan, sehingga mahasiswa butuh waktu untuk memahaminya. Alternatif pemecahannya yang akan dilakukan adalah artikel yang berisi isu yang mau didiskusikan dibagikan satu minggu sebelum pertemuan agar mahasiswa dapat membacanya terlebih dulu di rumah. Saat diskusi kelompok maupun saat diskusi kelas teridentifikasi keterampilan mahasiswa dalam mengeksplorasi atau mengali lebih dalam isu yang didiskusikan, mengevaluasi dan mengintegrasikan berbagai macam solusi belum begitu baik. Alternatif pemecahannya dosen akan berkeliling saat diskusi kelompok untuk memfasilitasi dan membimbing mahasiswa agar dapat mengeksplorasi dan mengevaluasi dan mengintegrasikan berbagai solusi secara konstruktif dan sistematis dengan tetap berpegang teguh pada prinsip model pembelajaran controversial issue yaitu prinsip keseimbangan artinya dosen meyakini mahasiswa memiliki konsep sendiri tentang pemecahan masalah, prinsip netralitas artinya dosen tidak menekankan pandangan pribadi dosen atau pendapat dosen terhadap isu tersebut dan prinsip tanggung jawab artinya dosen tidak berpihak atau partisipan terhadap suatu pendapat tertentu.

\section{Siklus Kedua}

Semua perencanaan yang dilakukan pada siklus pertama juga dilakukan pada siklus kedua, yang membedakannya adalah materi yang dibahas adalah mengenai konstitusi dan rule of law atau penegakan hukum. Berbeda dengan siklus pertama, artikel yang berisi isuisu kontroversi yang didiskusikan sudah disiapkan dibagikan satu minggu sebelum pertemuan perkuliahan dilakukan. Pelaksanaan siklus kedua ini berlangsung selama 4 kali pertemuan. Adapun isu controversial tentang konstitusi yang dibahas adalah isu "Perlukah UUD NRI 1945 di amandemen lagi?" dan isu tentang penegakan hukum yang mengangkat isu "Reformasi Lembaga Penegak Hukum", dan "Masihkah KPK dibutuhkan?"

Treatment pada siklus kedua ini dimulai dengan membagikan isu-isu yang akan dibahas serta pembagian kelompok seminggu sebelum perkuliahan. Kepada setiap mahasiswa diwajibkan di rumah membaca isu controversial yang dibahas dan membuat catatan tentang masalah apa yang terjadi dalam artikel tersebut, apa penyebabnya dan apa solusi atau pemecahannya Pada waktu pelaksanaan semua langkah-langkah pelaksanaan model pembelajaran controversial issue seperti siklus pertama dilakukan. Hal yang ditambahkan adalah kepada mahasiswa ditegaskan kalau mereka harus taat waktu berkaitan alokasi waktu untuk setiap tahap kegiatan.

Pada saat diskusi kelompok dan brainstorming terlihat kegiatannya berjalan 
cukup lancar dan tidak butuh waktu terlalu lama karena semua mahasiswa (anggota kelompok) sudah membaca isu yang dibahas di rumah. Diskusi lebih terfokus pada bagaimana mengevaluas $i$ dan mengintegrasikan berbagai pendapat dari anggota kelompok. Ketika diskusi kelompok sedang berjalan, dosen berkeliling pada setiap kelompok untuk memfasilitasi dan membimbing mahasiswa agar dapat mengeksplorasi dan mengevaluasi dan mengintegrasikan berbagai solusi secara konstruktif dan sistematis.

Selanjutnya, hasil pengamatan terhadap jalannya proses perkuliahan pada siklus kedua menunjukkan proses perkuliahan berjalan sudah baik, hampir semua mahasiswa antusias mengikuti jalannya diskusi baik pada saat diskusi kelompok maupun diskusi kelas.

Hasil pengamatan terhadap keterampilan berfikir kritis mahasiswa pada siklus kedua didapatkan data sebagaimana digambarkan pada diagram berikut:

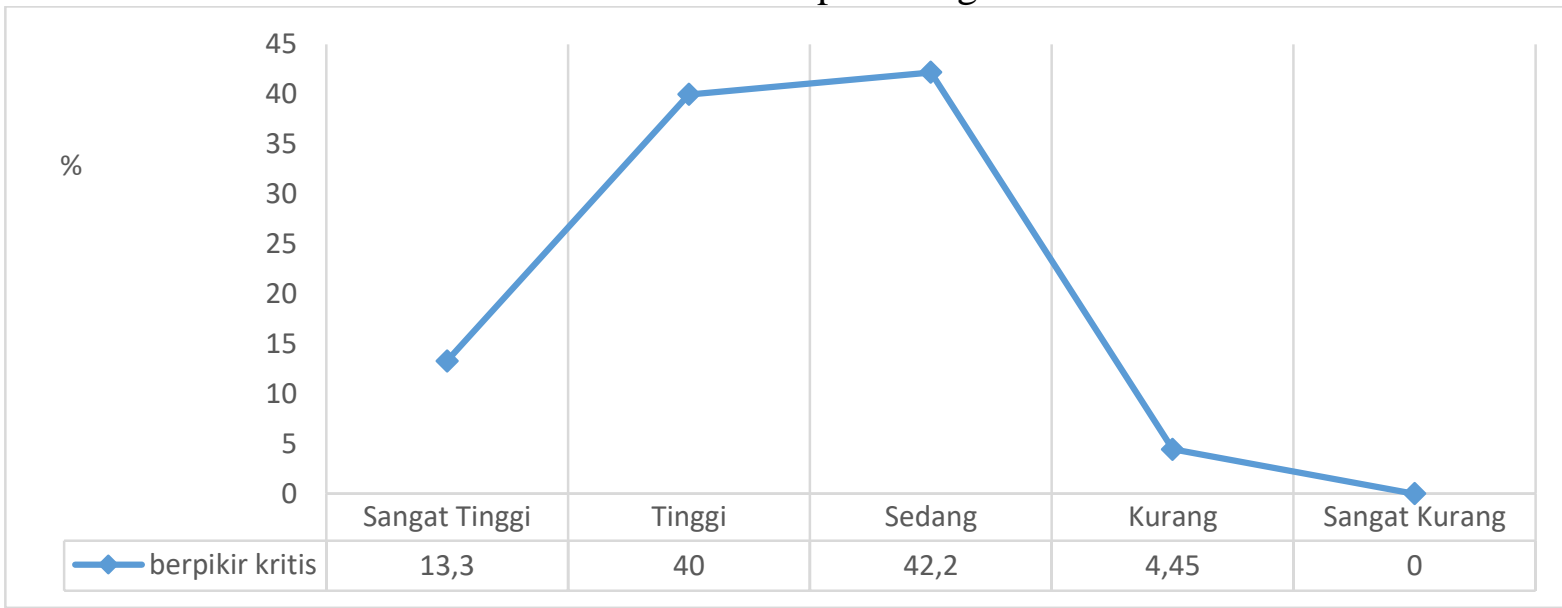

Diagram 2: kemampuan berfikir kritis mahasiswa pada siklus kedua

Dibandingkan dengan siklus yang pertama, terjadi peningkatan dalam kemampuan berfikir kritis mahasiswa. Di siklus pertama hanya 10 mahasiswa saja yang memiliki tingkat berfikir kritis tinggi dan sangat tinggi sedangkan di siklus kedua meningkat menjadi 24 mahasiswa. Namun masih bias dilakukan peningkatan yang lebih maksimal. Meningkatnya hasil di siklus kedua ini, menguatkan pendapat yang dikemukakan oleh Wiriaatmadja (dalam Komalasari, 2010:270) mengemukakan kelebihan menggunakan model pembelajaran Controversial Issues, yaitu: (1) mengajarkan kepada siswa kemampuan akademis untuk membuat hipotesis, mengumpulkan data-data, menganalisis data yang terkumpul, dan menyajikan hasil inkuiri, dan (2) melatih siswa untuk menghadapi kehidupan sosial yang kompleks dengan keterampilan berkomunikasi, menanamkan rasa empati, mempengaruhi orang lain, toleran, bekerja sama, dan lain-lain.
Selanjutnya, berdasarkan hasil observasi terhadap keterampilan berfikir kritis mahasiswa pada siklus kedua dilakukan evaluasi untuk, menentukan kategori atau kondisi mahasiswa. Hasil evaluasi menyimpulkan bahwa pada siklus kedua ini kemampuan berfikir kritis mahasiswa berada pada kategori instruksional, dimana terdapat 24 orang atau $53.33 \%(40 \%-60 \%)$ mahasiswa yang memilki nilai kemampuan berfikir kritis tinggi dan sangat tinggi. Hasil tersebut menunjukkan adanya peningkatan dari siklus pertama.

Tahapan terakhir dari siklus kedua, yaitu refleksi terhadap jalannya proses perkuliahan dengan menggunakan model controversial issue Pada siklus kedua diidentifikasi hal positif dan masalah yang muncul yang akan diperbaiki pada siklus ketiga dengan melakukan beberapa treatment atau perlakuan tertentu.

Disamping hal positif yang muncul pada siklus pertama tetap berlangsung, 
diidentifikasi hal positif baru dalam pelaksanaan siklus kedua ini, antara lain: (1) observer pada saat melakukan observasi terhadap kemampuan berfikir kritis mahasiswa tidak lagi mengalami kesulitan mengetahui nama tiap mahasiswa karena setiap mahasiswa memakai name tag, dan (2) tahapan-tahapan pembelajaran dengan model controversial issue berjalan sesuai dengan rencana. Pada saat diskusi kelompok, kemampuan berfikir kritis mahasiswa pada indikator keterampilan mengidentifikasi, mendefinisikan dan mengeksplorasi masalah sudah baik diskusi kelompok berjalan efektif sesuai dengan alokasi waktu yang diberikan dosen. Lancarnya kegiatan diskusi kelompok ini karena bahan atau isu yang didiskusikan sudah dibagikan seminggu sebelum perkuliahan berlangsung, sehingga semua mahasiswa sudah membacanya di rumah. Diskusi di dalam lebih bertujuan menyamakan persepsi dari setiap anggota kelompok untuk mendapatkan jawaban kelompok sehinga diskusi lebih terarah Disamping itu saat diskusi kelompok dosen juga berkeliling ke setiap kelompok membantu memfasilitasi mahasiswa merumuskan jawaban secara konstruktif dan sistematis

Pada siklus kedua ini, peneliti tidak terlalu menemukan permasalahan yang cukup besar karena peneliti sudah mencoba untuk menerapkan langkah-langkah pembelajaran controversial issue. Pada saat diskusi kelas partisipasi mahasiswa dalam menyampaikan pendapat, bertanya, mengklarifikasi semakin besar dan tinggi. Meningkatnya partisipasi mahasiswa juga didukung oleh penyajian isu yang mampu mendukung implementasi pembelajaran controversial issue. Sebagaimana dikemukakan oleh Solihatin (2012:96) mengemukakan bahwa ada beberapa prinsip yang harus diperhatikan ketika memilih isu kontroversial yang akan digunakan pada penerapan model pembelajaran Controversial Issues, yakni tidak menimbulkan pertentangan suku, agama, ras, dekat dengan kehidupan, sudah menjadi milik msyarakt dan berkenaan dengan masalah setempat, nasional, maupun internasional (Solihatin, 2012).

Selanjutnya dari analisis hasil observasi terhadap kemampuan berfikir kritis mahasiswa pada siklus kedua ini teridentifikasi bahwa kemampuan berfikir kritis mahasiswa pada indikator keterampilan mengevaluasi dan mengintegrasikan berbagai macam solusi menjadi suatu jawaban yang komprehensif masih kurang atau rendah Ketika diskusi kelas terlihat rasa ego kelompok maupun individu masih terlihat. Setiap kelompok cenderung memandang jawaban merekalah yang paling benar, kurang bisa menghargai pendapat orang lain dan megambil nilai positif dari jawaban orang lain. Kemampuan menggabungkan atau mengintegrasikan berbagai macam solusi yang muncul saat diskusi masih belum begitu baik.

Dari hasil diskusi tim peneliti disepakati perlakuan yang akan diberikan untuk mengatasi masalah tersebut diantaranya dosen sebagai fasilitator pada akhir kegiatan diskusi kelas memfasilitasi dan meminta setiap kelompok mendiskusikan dan menuliskan hal hal positif dari jawaban terhadap solusi masalah yang dikemukakan oleh kelompok lain dan setiap kelompok juga diminta mendiskusikan dan kemudian mengintegrasikan atau menggabungkan berbagai solusi menjadi satu jawaban yang komprehensif, konstruktif dan sistematis Setelah didiskusikan dikelompok, setiap individu mahasiswa diminta menuliskannya di lembaran kertas dan kemudian dikumpulkan ke dosen. Penulisan solusisolusi positif yang berasal dari kelompok lain, juga melatih mahasiswa untuk menjadi pribadi yang merasa paling benar atau baik, mereka juga diajarkan untuk tidak menutup terhadap hal-hal positif yang dimiliki oleh orang lain sehingga pada akhirnya akan menghasilkan pendapat atau solusi terbaik dari pikiran bersama Hal ini senada dengan yang ditemukan Solihatin (2012, hal. 95) bahwa "pengajaran dengan menggunakan isu kontroversial, keuntungannya adalah melalui pendapat yang berbeda dari beberapa orang dapat mengembangkan pendapat baru yang 
lebih baik karena terjadi proses analogis, sintesis dalam berpikir kritis".

\section{Siklus Ketiga}

Semua kegiatan pada perencanaan yang dilakukan pada siklus pertama dan kedua juga dilakukan pada siklus ketiga, yang membedakannya adalah materi yang dibahas adalah mengenai "Hak Asasi Manusia (HAM)" dan "Geo Politik Indonesia" (Wawasan Nusantara). Selanjutnya pelaksanaan siklus ketiga ini berlangsung selama 4 kali pertemuan. Adapun isu kontroversial tentang HAM yang diangkat untuk didiskusikan adalah tentang "SKB 3 Menteri tentang Pelarangan Penyebaran Ajaran Ahmadiyah di Indonesia" dan "Hukuman Mati" dan isu tentang Geo Politik Indonesia yang dibahas adalah isu tentang "Indonesia Sebagai Poros Maritim".

Treatment pada siklus ketiga berlangsung pada saat akhir kegiatan diskusi kelas, dimana dosen memfasilitasi dan meminta mahasiswa mendiskusikan dan menuliskan hal-hal positif dari jawaban terhadap solusi masalah yang dikemukakan oleh kelompok lain Disamping itu mahasiswa juga diminta mengintegrasikan atau menggabungkan berbagai alternatif solusi menjadi satu jawaban yang komprehensif, konstruktif dan sistematis. Kedua tugas itu ditulis secara individu pada kertas dan kemudian dikumpulkan.

Pengamatan terhadap jalannya proses perkuliahan pada siklus ketiga ini menyimpulkan jalannya proses perkuliahan dengan menggunakan model controversial issue berlangsung dengan lancar dan sangat baik. Mahasiswa sudah mengerti dan paham dengan langkah dan tugas apa yang harus kerjakan. Lancarnya pelaksanaan kegiatan pembelajaran tentu saja dikarenakan mereka sudah mengenal dan melaksanakan pembelajaran pada siklus pertama dan kedua sebanyak 8 kali pertemuan

Hasil pengamatan terhadap keterampilan berfikir kritis mahasiswa pada siklus ketiga didapatkan data sebagaimana digambarkan pada diagram berikut:

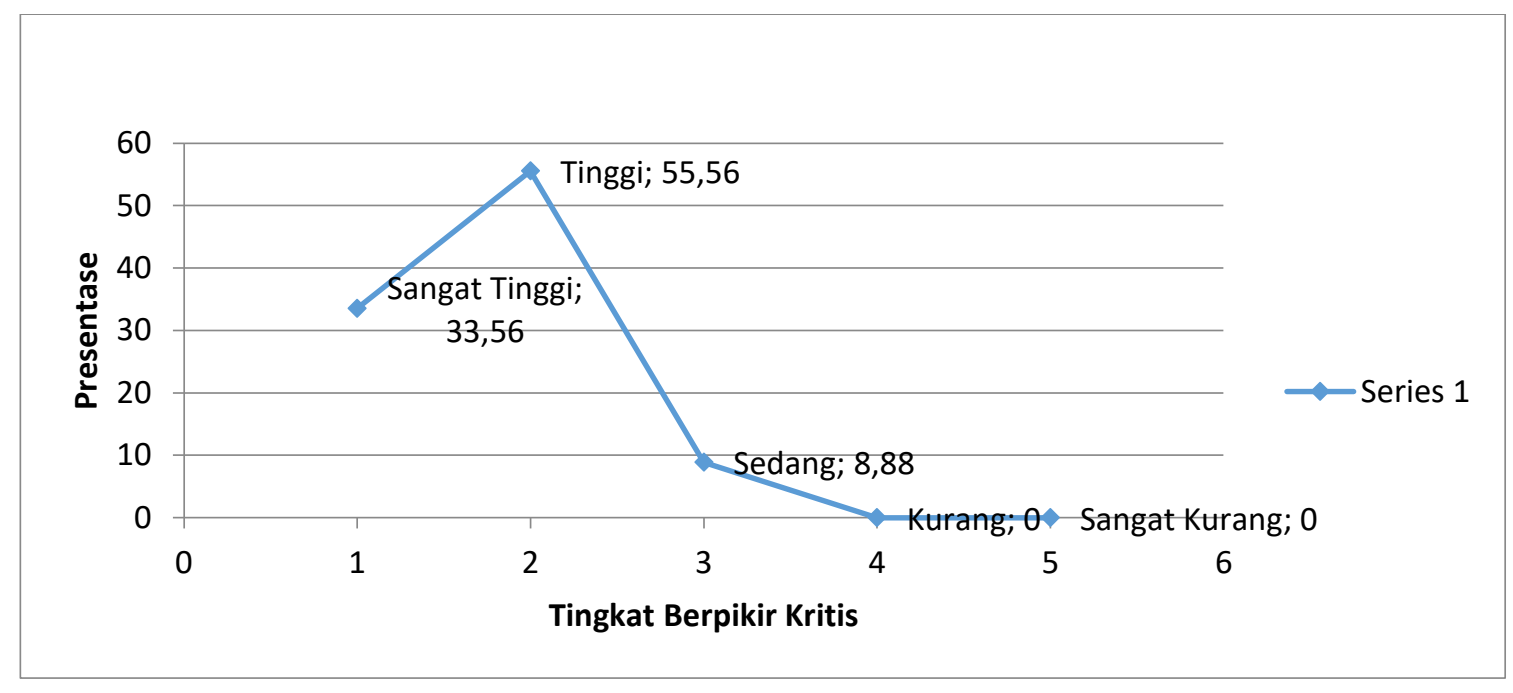

Diagram 3. Kemampuan berfikir kritis mahasiswa pada siklus kedua

Data di atas menunjukkan sebanyak 16 orang $(35.56 \%)$ mahasiswa memiliki nilai kemampuan berfikir kritis kategori sangat tinggi, 25 orang $(55.56 \%)$ memiliki nilai kemampuan berfikir kritis tinggi dan 4 orang $(8.88 \%)$ memilki nilai kemampuan berfikir kritis sedang. Pada siklus ketiga ini, permasalahan berpikir kritis mahasiswa sudah bias diatasi karena data menunjukkan bahwa tidak ada lagi mahasiswa yang berada di tingkat rendah atau sangat rendah dalam kemampuan berpikir kritisnya.

Hasil evaluasi menyimpulkan bahwa pada siklus ketiga ini kemampuan berfikir kritis mahasiswa berada pada kategori independent, karena persentase mahasiswa 
yang memiliki kemampuan berfikir kritis tinggi dan sangat tinggi lebih dari $60 \%$, di mana terdapat 41 orang atau $91.12 \%$ mahasiswa yang memiliki nilai kemampuan berfikir kritis tinggi dan sangat tinggi. Selanjutnya hasil refleksi terhadap jalannya proses perkuliahan dengan menggunakan model controversial issue pada siklus ketiga ini tidak ditemukan lagi masalah dalam proses pembelajaran yang berkaitan dengan kemampuan berfikir kritis mahasiswa. Tidak ditemukannya lagi masalah ini erat kaitannya dengan treatment yang dilakukan pada siklus pertama, kedua dan ketiga.

Disamping hal positif yang muncul pada siklus pertama dan kedua tetap berlangsung, diidentifikasi hal positif baru dalam pelaksanaan siklus ketiga ini, yaitu berupa meningkatnya keterampilan berpikir kritis mahasiswa pada indikator keterampilan mengevaluasi dan mengintegrasikan.

Dari analisis terhadap tugas tertulis yang diberikan dosen pada setiap individu mahasiswa pada akhir diskusi kelompok terlihat mahasiswa sudah terampil dalam membuat keputusan atas berbagai macam solusi terhadap suatu masalah. Mahasiswa sudah bisa menghargai dan mengambil nilai positif dari jawaban mahasiswa atau kelompok lain. Selanjutnya juga teridentifikasi mahasiswa sudah mampu mengintegrasikan berbagai macam alternatif pemecahan masalah menjadi suatu solusi yang komprehensif, konstruktif dan sistematis dalam memahami dan memecahkan masalah.

\section{Simpulan}

Implementasi model pembelajaran controversial issue dapat meningkatkan kemampuan berfikir kritis mahasiswa dalam pembelajaran mata kuliah Pendidikan Kewarganegaraan. Model pembelajaran controversial issue dapat meningkatkan keterampilan mahasiswa dalam mengidentifikasi masalah, mendefinisikan masalah, mengeksplorasi masalah, mengevaluasi dan mengintegrasikan berbagai macam solusi menjadi suatu jawaban yang komprehensif terhadap suatu permasalahan.

\section{Referensi}

Citizenship Foundation. (2003). Teaching about controversial issues: guidance for schools.

Fisher, A. (2009). Berpikir kritis sebuah pengantar. Jakarta: Erlangga.

Hess, D. (2001). Teaching in public controversy in democracy. In J. J. Patrick \& R. S. Leming (Ed.), Principles and practices of democracy in the education of social studies teachers. Civic learning in teacher education. Bloomington, IN: ERIC Clearinghouse for Social Studies/Social Science Education, ERIC Clearinghouse for International Civic Education, and Civitas.

Hoskins, B., Villalba, E., Van Nijlen, D., \& Barber, C. (2008). Measuring civic competence in Europe. JRC Scientific and Teaching Reports. Ispra, Italy. https://doi.org/10.2788/67916

Komalasari, K. (2013). Pembelajaran kontekstual: Konsep dan aplikasi. Bandung: Refika Aditama.

Lai, E. R. (2011). Critical thinking: A literature review (Research report). Pearson Research Report. Diambil dari http://images.pearsonassessments.com/i mages/tmrs/CriticalThinkingReviewFIN AL.pdf

Lockwood, A. L. (1995). Controversial issues: The teacher's crucial role. Social Education.

Muhibbin, A., \& Sumardjoko, B. (2016). Model pembelajaran Pendidikan Kewarganegaraan berbasis isu-isu kontroversial di media massa untuk meningkatkan sikap demokrasi mahasiswa dan implikasinya bagi masyarakat madani. Jurnal Pendidikan Ilmu Sosial, 26(1), 1-10.

Mulyasa, E. (2005). Menjadi guru profesional menciptakan pembelajaran kreatif dan menyenangkan. Bandung: Remaja Rosdakarya.

O'Hare, L., \& McGuinness, C. (2009). Measuring critical thinking, intelligence, and academic performance in 
psychology undergraduates. The Irish Journal of Psychology, 30(3-4), 123131.

Samsuri. (2011). Model pembelajaran Pendidikan Kewarganegaraan untuk membangun komperensi warga negara. In Kuliah Umum di Program Studi Pendidikan Pancasila dan Kewarganegaraan (PPKn) FKIP Universitas Ahmad Dahlan 9 Mei 2011 (hal. 1-13). Yogyakrta.

Solihatin, E. (2012). Strategi pembelajaran $P P K N$. Jakarta: Bumi Aksara.

Suryanto, \& Nursalim. (2015). Analisis teoritik model pembelajaran berlatar isuisu kontroversial. In Nusantara of Research (Vol. 22, hal. 178-184). 